\title{
ILCEA
}

Revue de l'Institut des langues et cultures d'Europe, Amérique, Afrique, Asie et Australie

$11 \mid 2009$

Langues \& cultures de spécialité à l'épreuve des médias

\section{Journalism FASP \& Fictional Representations of Journalists in Popular Contemporary Literature}

Shaeda Isani

\section{OpenEdition}

Journals

Édition électronique

URL : https://journals.openedition.org/ilcea/251

DOI : 10.4000/ilcea.251

ISSN : 2101-0609

Éditeur

UGA Éditions/Université Grenoble Alpes

Édition imprimée

ISBN : 978-2-84310-179-3

ISSN : 1639-6073

Référence électronique

Shaeda Isani, « Journalism FASP \& Fictional Representations of Journalists in Popular Contemporary Literature », ILCEA [En ligne], 11 | 2009, mis en ligne le 20 mars 2023, consulté le 20 mars 2023. URL: http://journals.openedition.org/ilcea/251 ; DOI : https://doi.org/10.4000/ilcea.251

Ce document a été généré automatiquement le 20 mars 2023.

Tous droits réservés 


\title{
Journalism FASP \& Fictional Representations of Journalists in Popular Contemporary Literature
}

\author{
Shaeda Isani
}

1 Journalism and journalists are recurrent features of popular fiction and fictional representations of the profession and its professionals constitute a growing field of academic enquiry. This article looks at how authorial imagination seeks to integrate the profession into the fabric of the fictional construct. The scope of the study concerns British and American popular literature from the second half of the $20^{\text {th }}$ century till today and focuses on two lines of enquiry, the definition of a recently identified literary genre (FASP) and its journalism sub-genre (journalism FASP), and the fictional representations that this specialised sub-genre projects of journalists.

2 In this respect, it is important to pre-empt potential misunderstandings with reference to a deceptively similarly named genre, called 'fictionalised journalism', or 'literary journalism'. ${ }^{1}$ Launched in the 1960s and described by Tom Wolfe, one of its pioneers, as "Journalism that would... read like a novel" (1973: 21), the genre borrows heavily from conventional dramatic literary techniques, (scene by scene construction, use of extended dialogue, third person point of view, use of details, subjectivity, etc.). Nevertheless, however much it may read like fiction, its narrative is based not on fictional but real life events, facts and people. Frequently cited examples are Truman Capote's In Cold Blood (1965) and - particularly relevant in the context of our study Woodward \& Bernstein's All the President's Men (1974). In contrast to fictionalised journalism, the subject of this study is fiction about journalism in which, even if certain real life people may figure, plot and protagonists are, to use the hallowed expression, "products of the author's imagination". 


\section{Introducing the FASP. fiction à substrat professionnel}

$3 \quad$ Fiction based on the creative conceit of generating plot dynamics within the context of a defined professional environment, if not a new literary device, became a sufficiently widespread phenomenon in popular literature in the latter half of the $20^{\text {th }}$ century to warrant special critical attention. Though critics isolated and identified various manifestations of the genre as "Lawyer novels", "Medical novels" or "Technical thrillers", no attempt had been made towards establishing the genericity of such works of fiction until 1998 and 2000 when Michel Petit published two founding texts in which he isolated and defined a new literary genre, fiction à substrat ${ }^{2}$ professionnel or FASP3 ${ }^{3}$.

4 The seminal analysis defined the new genre on the basis of a number of common core characteristics which may be summarised into three broad defining conventions, the novel's contemporary setting, it's appurtenance to the thriller or mystery novel genre and finally, the eponymous substrat professionnel, the professional environment which nourishes the plot, defines the characters and shapes the denouement.

$5 \quad$ FASP authors craft their substrat professionnel from a wide variety of subject domains and more often than not, are or have been members of the profession they choose to fictionalise. Amongst the most popular substrat professionnels are legal FASP (John Grisham, John Mortimer, Scott Turow), medical FASP (Robin Cook and Tess Gerriston), art FASP (Iain Pears), techno-military FASP (Tom Clancy), police procedural FASP (P.D.James, Ian Rankin, James Patterson, Michael Connolly, etc.), political FASP (Michael Dobbs), scientific FASP (Michael Crichton, Kathy Reichs), not to mention journalism FASP...

6 FASP is a genre with covers diversified media ranging from books, films and television and its journalism sub-genre is particularly diversified in this respect. The best known examples of the sub-genre are clearly to be found in the cinema with such iconic films as Citizen Kane (1941), All the President's Men (1976) and, more recently, Good Night, and Good Luck (2005). Television journalism FASP is also a well-represented genre, particularly in the United States, with such series as Murphy Brown, Breaking News, Mary Tyler Moore and Big News.

7 Book journalism FASP, contrary to other FASP sub-genres such as legal FASP, is a less prolific field and the most frequently cited example, Bernstein \& Woodward's All the President's Men (1974), does not qualify as journalism FASP since, as mentioned earlier, it is not a work of fiction but a true story borrowing heavily from literary narrative techniques. Such fusion between the imaginary and the real - cf. the above-mentioned Citizen Kane and Good Night, and Good Luck - is a recurrent trait in journalism-related fiction as pointed out by Joe Saltzman (undated) on the Image of the Journalist in Popular Culture website:

The popular image of the journalist swirls between the real and the fictional without discrimination. The public memory seldom distinguishes between the actual and the non-real. Often the two are linked together. Larger-than-life fictional characters overwhelm their less vivid real-life contemporaries. Real-life journalists become so immersed in legend and distortion that their images are as surrounded by fiction as any character in a novel, film or TV program. Who is real? Who is fiction? [En ligne]

A more unusual media support specific to journalism FASP is comic books and comic strips. Comic album readers have for generations followed the exploits of Superman 
and Spiderman of The Daily Planet and The Daily Bugle respectively, while readers of The Chicago Tribune are familiar with those of comic strip journalist Brenda Starr. More recently, in 2004, Mike Sangiacomo, himself a general assignment reporter for Cleveland's Plain Dealer, revived the genre with a comic series whose protagonist is The Clarion's Jack Baxter, aka Phantom Jack. Following a more humoristic trend, European comic book journalism FASP identifies with the Francophone bande dessinée tradition with the legendary Belgian Tintin and such popular French figures as Spirou and Fantasio.

9 Research activated by the generic codification of the FASP has tended, like the proverbial disciple who exceeds his mentor, to broaden the initial frontiers of the genre (Isani 2004). This is particularly relevant with reference to two criteria which, if strictly applied, narrow down the scope of the genre. The first of these generic constraints resides in Petit's situating the rise of the genre to around the 1980s which results in the exclusion of such otherwise exemplary FASP works as Erle Stanley Gardner's emblematic Perry Mason books with regard to lawyer FASP, for example. The second restrictive convention concerns the need for a FASP novel to be a thriller, thus excluding other related forms such as adventure novels, for example. These two generic criteria combine to exclude a journalism-related classic, Evelyn Waugh's The Scoop (1938), from consideration as journalism FASP since it is a parody which is neither popular nor contemporary and relates more to the adventure genre than the thriller, even though for David Lodge (1992: 14) the 'whodunnit' and the 'what happens next' are simply two variations of the suspense novel.

\section{Journalism FASP}

10 Journalism has been a popular fictional support ever since the advent of mass journalism in the late $19^{\text {th }}$ century and the resulting fusion has generated a rich field of academic enquiry. Most research relative to this area has, however, adopted a diachronic focus, as for example Howard Good's Acquainted with the Night: The Image of Journalists in American Fiction, 1890-1930 published in 1986. In a similar approach focusing on the $20^{\text {th }}$ century, Matthew Ehrlich (2002: 507-514) divides journalism-related cinematic fiction into five main periods: 'The Front Page and early journalism movies' which he situates in the first quarter of the $20^{\text {th }}$ century; 'The screwball era' of the 1930s and 1940s centred on 'newsmonger' characters; the post-war 'noir era' with the appearance of the 'bad' journalist; 'Conspiracy films' of the 1970s represented by the emblematic All the President's Men by Alan J. Pakula; and finally, 'Contemporary films' which mark the post-Watergate era. The present study focuses essentially on this last era.

11 Even though, as mentioned earlier, certain core conventions of the FASP genre may prove too confining at times, the delineation of a specific timeframe with reference to journalism FASP does, paradoxically, appear a valid generic criterion. The sweeping technological and social changes brought about with the advent of the internet has so transformed the practices and ethos of the profession that it would not be inappropriate to evoke the turn of the century as a demarcation between two journalistic cultures. The corpus of analysis which informed this study, though extending into the $21^{\text {st }}$ century, tends to focus on the post-war evolution of journalismrelated literature rather than the rising forms of internet-related journalism. 

domains such as law, mathematics or geography, it is not a self-standing and autonomous profession. By the very nature of the profession, journalism is heavily dependent on an adjunct referential domain without which it cannot exist, a typically symbiotic relationship arising from the former's need for matter to disseminate and the latter's need to be disseminated. As a consequence, in order to be significant, journalism must necessarily be grafted onto some other area of human activity or interest, a subsidiary support subject-domain such as politics, international relations, the environment, economy and finance, sports, science, justice, crime and law, gardening, etc.

In terms of creative writing, the symbiosis between journalism and its support domain ideally translates into a narrative tandem in which the two fields mesh to occupy equal weight, thus generating a twin substrat professionnel. Michael Dobbs's first novel, House of Cards (1989), is one such example. In this "Watergate set in Westminster" according to The Daily Telegraph, plot and character dynamics are devised in terms of a twin substrat professionnel which makes it difficult to determine whether the novel should be classified as journalism or political FASP: is the protagonist Mattie Storin, the young political correspondent, or Francis Urquhart, the Chief Whip? Is the focus of the plot the political battle for Downing Street or the press investigation into behind the scenes political skulduggery?

Similarly, the 1999 film The Insider - albeit not entirely fiction - is also an example of how two interdependent domains segue to create a twinned substrat professionnel: who is the protagonist, Bergman the journalist or Wigand the defector from Big Tobacco? Is the focal interest of the plot the denouement concerning the publication of the story or the fate of Wigand? unbalanced picture of the piggy-back nature of journalism. How and to what degree the journalism substrat professionnel intersects with other fields of activity is one of the characteristic hallmarks of the sub-genre and allows for a larger palette of 'FASPness' than is usual with other sub-genres, such as legal and medical FASP, for example.

In this context, Petit's distinction between adstrat ${ }^{4}$ professionnel and substrat professionnel (1999: 67) provides a useful starting point for analysing differing degrees of 'FASPness'. (Isani 2004: 34)

\section{Degrees of 'FASPness': adstrat or substrat professionnel?}

The degrees to which journalism and journalists are integrated into plot and character construction vary considerably. Paul Steinle in Print (and Video) to Screen: Journalism in motion pictures of the 1990s (2000) classifies journalism-related fiction into four categories: fiction in which journalists are the key characters, fiction in which journalism itself is the predominant focus, fiction in which characters are cast as journalists but their professions reflect little on the plot and finally, fiction in which journalists are merely transitional devices advancing the plot.

18 In spite of its pertinence to a large body of journalism-related fiction, Steinle's taxonomy blurs when confronted with, for example, the journalist protagonist (category 1) whose profession has little impact on the narrative (category 3 ) as is the case in John Irving's The Fourth Hand, (2001) or again, when journalists as a collective 
body recurrently interact with the protagonist as in Elizabeth George's cricket FASP, Playing for the Ashes (1994). Using the concept of substrat professionnel as a taxonomical criterion allows for retaining a number of Steinle's criteria while at the same time finetuning classification.

To meet substrat professionnel criteria, the professional environment of the work of fiction must constitute the creative pivot of characterisation, plot and denouement, as we have defined elsewhere:

To qualify as substrat professionnel, the specific culture of the professional community, its processes and procedures, discourse, cultural representations and perceptions, etc., must be the foundation of the creative process and the springboard of the fictional conceit. (2004: 26)

Anything less is necessarily a weaker form of the genre. However, one of the particularities of journalism-related fiction is the degree to which it reflects the characteristic reliance of the profession on a subsidiary subject-domain. The two domains interact in shifting patterns of correlation and varying degrees of 'FASPness'. In this respect, and according to how closely the author weaves the professional environment into the fabric of the fiction, four broad degrees of 'FASPness' may be defined in relation to journalism FASP.

\section{Mainstream journalism FASP}

21 As in other FASP genres, the creative dynamics of mainstream journalism FASP are inextricably embedded in the profession. If the legal sub-genre is shaped by law courts, law firms, law professionals, legal culture, legal events, legal discourse, etc., journalism FASP is similarly embedded in and shaped by journalism, its different media, its newsroom politics, its professional culture, its ethics, its professionals, its conflicts etc., all defined by the task of gathering and circulating information. In Denise Mina's novels, The Field of Blood (2005), The Dead Hour (2006) and The Last Breath (2007) the journalism substrat professionnel is defined by the confined universe of a Glaswegian newspaper, Scottish Daily News; Swedish author Lisa Marklund's The Bomber (2002), evolves around journalist Annika Bengtzon and Kvällspressen, the Stockholm newspaper she works for; the universe of Stieg Larsson's Millenium (2005) trilogy is the eponymous Stockholm-based monthly specialising in finance; the hub of Good Luck, and Good Night (2006) is naturally the CBS newsroom; and finally, the 'community journalism' depicted in Annie Proulx's The Shipping News (1993) is anchored in the newspaper office of The Gammy Bird.

Journalism's characteristic need to intersect with other fields of activity in order to exist as a profession is clearly reflected in journalism FASP where the journalism substrat professionnel engages with a subsidiary subject-domain through the convenient literary device of being transformed into the journalist protagonist's specialism or object of investigation. Hence, both Denise Mina's and Liza Marklund's journalist protagonists, called on to cover crime events, naturally assimilate police procedure into journalism, a frequent pairing in journalism FASP. In the same vein, in John Grisham's deceptively entitled The Last Juror (2004), the newspaper owner-cumjournalist protagonist's field of investigation is the law (and not the contrary as might have been expected in a Grisham novel). In a more unusual form of fictional pairing, Stieg Larsson's protagonist, Mikael Blomkvist, directs his journalistic investigative 
skills towards the murky world of Swedish high finance in The Girl with the Dragon Tattoo (2005).

\section{Journalism as an adstrat professionnel}

Although the protagonist in mainstream journalism FASP is typically a journalist whose investigation leads to engagement with a subsidiary subject-domain, there is also a considerable body of fiction in which the situation is reversed and it is the nonjournalist protagonist who engages with the press. In this category of journalism FASP, the media - represented as an individual journalist or a collective body - do not occupy the front stage but comprise nevertheless an interactive and recurrent presence through the protagonist's need to engage with the press. FASP A Time to Kill (1992) illustrate how the two professions mutually feed off each other, the press for the sensational story and the lawyer to ensure future business:

Publicity. Exposure. That's the name of the game for lawyers, Jake. If you're unknown, you starve. When people get in trouble they call a lawyer, and they call someone they've heard of. You must sell yourself to the public, if you're a street lawyer. (A Time to Kill, 1992: 105)

From his office he watched a camera crew set up by the rear door of the courthouse. He smiled and felt a wonderful surge of adrenaline. He could see himself on the evening news walking briskly, stern, businesslike, across the street followed by reporters begging for dialogue but getting no comments. And this was just the arraignment. Imagine the trial! Cameras everywhere, reporters yelling questions, front page stories, perhaps magazine covers. An Atlanta paper had called it the most sensational murder in the South in twenty years. He would have taken the case for free, almost. (A Time to Kill, 1992: 156)

In a similar vein, the following conversation between two senior police officers in Elizabeth George's sports FASP, Playing for the Ashes (1994: 394), provides another example of the mutual dependency of police and press, one of the underlying themes of the novel:

'What's your approach?'

'We generally tell them whatever will be useful to us.' ...

'Do you really? I've never told them a thing. I loathe symbiosis between press and the police.'

'So do I', Lynley replied. 'But it serves us sometimes.'

Such novels may be categorised as fiction a adstrat professionnel, term coined by Petit (1999: 67) to describe those works of fiction in which the professional environment, though present and perhaps even relatively active, does not constitute the bedrock of plot, character and denouement dynamics but is an accessory to the principal fictional construct.

\section{Metajournalism FASP}

Metafictional writing is "novels and stories that call attention to their fictional status and their own compositional procedures," (Lodge, 1992: 206), a literary genre which seeks its inspiration from within its own creative processes, as illustrated by such wellknown sub-genres as plays within the play, novels about novel writing or films about shooting films. In the same vein and in spite of the fact that one of the defining features of journalism is its inherently centrifugal vocation, there exists a centripetal and 
introverted sphere of journalism which focuses on its own profession, a form of metajournalism in which journalism adopts journalism as the focus of study, as illustrated by media analyses about other media and media professionals, ethical dilemma currently facing the profession, its future evolution, etc.

Similarly, a form of metajournalism FASP may also be identified in which the fiction is wholly contained within the profession itself, without the need to interact with a subsidiary subject-domain. Metajournalism FASP deviates from typical journalism FASP in that it seeks its plot and character dynamics from within its own profession - and in so doing, links up with mainstream FASP which focuses on a single substrat professionnel.

An emblematic example of fictional metajournalism would be the mythic Citizen Kane (1941). Though strictly speaking not eligible for FASP status given its age and genre though referred to by Jorge Luis Borges as "a metaphysical detective story" when released - the film occupies cult status as the first film to look into the then rising figure of the press magnate. A more contemporary example of an introspective approach to journalism is The Paper (1994) about a day in a journalist's life, or Good Night, and Good Luck (2005), a semi-fictionalised account of the role of the press during McCarthyism.

\section{The journalist as an intermittent player}

From substrat, to adstrat to intermittent player! There is a large amount of fiction in which a professional environment is used simply to serve as a more or less vague decor or incidental reference against which a totally unrelated plot evolves. In Louis Begley's About Schmidt (1997), the protagonist is indeed a lawyer but the evolution of plot and characters is in no way shaped by the legal profession. In the case of journalism, a novel with a similar equation would be John Irving's The Fourth Hand (2001) in which, despite the fact that the protagonist is by profession a journalist and that certain parts of the plot derive from his profession, plot dynamics owe less to a journalistic universe than a medical one. Such works of fiction, in which the professional environment is reduced to anecdotal status or is a mere setting for action which must seek its creative dynamics elsewhere, clearly do not belong to the FASP genre.

Whether cast as principal protagonists or intermittent players, fictional portrayals of journalists in popular fiction - whether novels, films, televisions series or comic books - project representations of the profession and its professionals which shape public perceptions. A major area of enquiry related to the FASP is concerned with the narrative processes which underlie the construction of such fictional representations. The following part of this study proposes to explore the fictional representations projected of the journalist in a selected corpus of journalism FASP novels.

\section{Fictional representations of the journalist in journalism FASP}

Authors who anchor their creative writing in the world of journalism have a wide palette of professionals to cast as protagonist: from the publisher or owner - the traditionally villainous 'press magnate', 'media tycoon', 'press baron' or 'media mogul' often fashioned from the larger than life role models as Randolph Hearst, Robert Maxwell or Rupert Murdoch today - to the editor, the reporter, the journalist, the 
copywriter, the broadcaster and the cub reporter. In spite of the plethora of choice, it is clearly the journalist - 'journo' for insiders - who is the fictional writer's protagonist of choice. One reason is undoubtedly the close similarities between the profiles of the investigative reporter and the detective, as underlined by Joe Saltzman:

The reporter as detective is probably one of the most popular categories, since both the journalist and the detective are curious enquirers trying to solve a mystery, whether it be a crime or a complex unknown story. They are both trying to piece together the various aspects of a puzzle, to come up with a reasonable conclusion to what happened, where it happened, when it happened, and to whom it happened, combined with the more difficult aspects of the story or case - how it happened and why it happened. (2002: 32)

The thriller convention of the FASP favours the portrayal of the journalist protagonist as an investigative and/or campaigning journalist, that half-detective reporter-cumjournalist, modelled on the likes of Woodward and Bernstein - a portrait far removed from the reality of current journalism in which the journalist is more likely to be a desk-bound internet surfer than "a roving reporter", as research in media studies reveals. (Bell 1993 [1991])

Research in the field of journalism-related popular literature has provided useful analyses with regard to how the different professions within the profession - editor, crime writer, war correspondent, 'sob sister', investigative reporter - have been the source of authorial inspiration and creativity. The object of this analysis is concerned with the figure of the journalist in a wider acceptation of the term. As Joe Saltzman points out, the definition of 'journalist' has evolved over the years and if, in the past, the journalist was more specifically perceived as being involved in the editing and writing activities of the profession, today, "He has become a synonym for reporting and writing in any news medium. [...] A journalist is defined as anyone in any century who performs the function of the journalist today - gathering and disseminating news, information, advice, editorial comment and criticism." (2002)

FASP protagonists generally come in a nuanced palette of representations. Lawyer FASP protagonists, for example, run the gamut from idealisation to demonisation and in between, with Harper Lee's Atticus Finch in To Kill a Mocking Bird (1960) as the embodiment of the profession's best and John Milton in Andrew Neiderman's The Devil's Advocate (1997) as the devil incarnate. (Isani, 2005)

Journalism FASP too boasts its equivalent of Atticus Finch. According to Ghiglione and Saltzman (2002), Clark Kent - aka as Superman - is "the most consistent heroic image of the journalist from 1938 to 2001 and beyond." According to Dennis Dooley, author of Superman at Fifty - The Persistence of a Legend (1987), Superman is modelled on real life reporter Wilson Hirschfield who once claimed he knew nobody with as much integrity as himself (a quotation often erroneously attributed to Superman himself), a conceit which led The Independent (16/09/03) to qualify the character as "the ultra-virtuous Clark Kent". That the fictional embodiment of the "good journalist" should be a relatively one-dimensional comic book journalist who masks his superhuman identity by cultivating the persona of an introverted, mild-mannered journalist - accused on occasion of cowardliness - provides an interesting composition in opposites.

37 Journalism FASP presents a more characteristic, albeit restrained, palette of representations than legal FASP for instance, in that depiction of the journalist tends to fall into two broad categories, the journalist as the lone protagonist, a flawed hero but 
hero nevertheless, or the journalist as a faceless, nameless, undistinguishable member of a professional herd.

\section{The journalist as protagonist: a flawed hero} heart of Denise Mina's The Dead Hour (2006) when the otherwise principled and sympathetically portrayed junior journalist protagonist, Paddy Meehan, accepts money in exchange for not reporting a story about a man assaulting his wife: 
He leaned forward and put something in Paddy's hand. 'I can't stress enough how important it is that this doesn't get in the paper.' It was a fifty-pound note. 'Please?' The note was damp and pink with blood. [...] Her cold fingers closed over the note. 'Good night.' He slipped back into the house and shut the door firmly but quietly. [...]

She had fifty quid in her hand. She squeezed it just to be sure it was there and the wetness of the blood chilled her. [...]

Billy watched her fall into the back seat in the rear-view mirror and took a draw on his cigarette. He had seen her take the money, she was sure of it. She could have offered to share it but she didn't know what the etiquette was, she'd never been bribed before. Besides, fifty quid could solve a host of problems. [...]

In the coming weeks and months she would recall how glad she had been to be back in the warm car and how thrilling the note had felt in her pocket. [...]

She looked sadly down at her hand as it uncurled in her lap. Her palm had blood on it.

(2006: 7-9)

The ensuing professional and personal conflicts which result from this particular example of hamartia are integrated into the narrative so as to relate to both the substrat professionnel and the crime plot itself - and consequently, having taken the initiative to right the wrong, the protagonist typically emerges aggrandised, gaining in personal and professional status.

\section{The journalist as a group entity. the anonymous pack}

The representation of the individual professional as a flawed hero-protagonist is a recurrent feature of FASP novels and journalism FASP is no exception in this respect. However, the representation of professionals as a group entity is a feature specific to the sub-genre and possibly, along with equally characteristic twinned substrat professionnel, a generic hallmark.

One of the highly visual images of journalism, relayed over news bulletins all over the world, is a mass of shoving and shouting journalists, armed with cameras and mikes an image authors faithfully transpose into their fiction resulting in the recurrent depiction of the members of profession as a faceless, nameless and collective entity. Faceless but not anodyne. In mainstream journalism FASP, the group portrayal tends towards the sympathetic, an insider's view of fellow-professionals' foibles as in the extract below from Denise Mina's The Last Breath:

They drove past Sean's street, stopping and peering down the road to see the hordes parked up outside the house. Photographers stood in groups, their bags at their feet, fingering their cameras and looking bored. Journalists stood separately She knew the scatter pattern well enough: clusters of the genial ones, gathering round to swap lies about their wages and expense accounts and all the coups they nearly had, the loners hanging about on the fringes, telling themselves lies and coming up with schemes to trounce the others to the story. A large television van was parked up on Sean's side of the road, a massively tall transmission aerial sticking out of the top. She could already imagine the complaints from the press journalists: the van would be in their view, spoil the pictures. But that was why it was there, to get the logo in any of the pictures that published and show that STV were on the scene too. (2007: 273-274): systematically and uniformly depicted as a sinister and menacing horde as illustrated 
by in Elisabeth George's Playing for the Ashes, a sports FASP in which journalism is an adstrat professionnel:

No, she said to herself, she wouldn't give anyone the flaming satisfaction of seeing her break down another time. Not after yesterday afternoon with those cameras clicking in her face and the reporters like jackals, circling fast and sussing her out, waiting for a show of weakness to record. Well, they'd got their show and mashed it across the front of the paper and that was all that she intended to give the bastards. (1994: 514)

In this respect, a breakdown of the recurrent metaphors used to carry and sustain such negative depictions is edifying as seen in the following sampling gleaned from the same novel:

Fig. 1 Metaphorical representations of journalists as a group Elizabeth George, Playing for the Ashes (1994)

\begin{tabular}{|l|l|}
\hline Verbs & to bay, to besiege, to circle, to dog, to hound, to lie in wait, to prowl, to swarm \\
\hline $\begin{array}{l}\text { Collective } \\
\text { nouns }\end{array}$ & army, flock (of crows), gaggle, herd, horde, pack, mobs, posse \\
\hline Nouns & $\begin{array}{l}\text { bastards, berks, carrion eaters, crows, dogs, ghouls, hyenas, jackals, wolves, } \\
\text { vampires, sharks, sleaze, slugs, wallies }\end{array}$ \\
\hline
\end{tabular}

Semantic analysis of the metaphorical representation of journalists in the novel reveals an easily discernible patterning according to which the verbal metaphors tend towards a common semantic denominator suggestive of pursuit and entrapment; collective nouns are unambiguously denotative of menacing masses; and, perhaps most interestingly, individual nouns recall the profession's parasitic dependence on a subject-domain in that many of the metaphors are evocative of scavengers or fantastic human-predators. Such metaphorical representations of the profession, albeit particularly egregious in the novel in question, are not infrequent in journalism FASP.

\section{Conclusion}

Public opinion polls regularly show that certain professions, such as lawyers, politicians and journalists, do not enjoy the public's confidence. One striking element in this respect is that journalists are distrusted by the very public they write for. According to a nationwide 2007 Gallup poll for ABC, if $64 \%$ of Americans have an overall positive perception of their press, only $14 \%$ expressed "a great deal of confidence". Similarly, a 2007 YouGov poll published by The Economist (May $5^{\text {th }}$ 2007: 41) showed an almost $20 \%$ loss of confidence in the press since $2003^{5}$ in the United Kingdom, a country which represents the world's largest newspaper readership in relation to population. The negative public perceptions recorded by opinion surveys and the negative image generated by journalism FASP give rise to the obvious chicken-or-the-egg question: is it fiction that shapes perceptions or perceptions that inspire fiction?

While there is no clear answer, an important consideration with regard to this question is the nature of the relationship between the journalist and the public: it is necessarily a vicarious, media-interposed encounter. Paradoxically, though the journalist is often a 
public figure, he is not a professional the lay public is likely to encounter in the routine course of events, as is the case with other professionals such as doctors, dentists, teachers, policemen or even lawyers.

Likewise, if the previously closed world of law courts has been considerably demystified by live court TV channels and cinematic legal FASP, the same degree of exposure has not benefited journalism and journalists. There is subsequently, a certain vacuum in the layman's mind as to what the real world of journalism is like: What does a newsroom actually look like? What are the different functions of publishers, editors, sub-editors, etc.? How are newspapers printed? How is a radio programme broadcast? What does a prompter look like? This vacuum is filled by entertainment and news media representations, blurring the lines between fiction and reality as Joe Saltzmann indicates:

The reality is that few people ever witness a journalist in action. They rarely visit a newspaper or magazine office or a broadcast newsroom or any other place where journalists work to report the news of the day. And yet they have a very specific idea of what a journalist is and what he or she does because they have read about journalists in novels, short stories and comic books, and they have seen them in movies, TV programs, plays, and cartoons. (2002: 41)

Negative and/or flawed perceptions of the profession could arguably be off-set by the discourse of positive self-representation promoted by real-life journalists or even by the fictional protagonist whose heroic but flawed character draws him empathically closer to the reader. However, findings of opinion surveys clearly indicate that the journalist continues to be found wanting in the eyes of the general public - no doubt a tribute to the sustaining power of the discourse of excess as relayed through exaggerated headlines, tabloid vulgarity, visual images of jostling reporters - and journalism FASP.

\section{BIBLIOGRAPHIE}

\section{Primary references}

Novels

Begley, Louis. 1997. About Schmidt. New York, Balantine.

Bernstein, Carl \& Bob Woodward. 1976. All the President's Men. New York, Touchstone.

Capote, Truman. 1966. In Cold Blood. New York, Vantage Books.

George, Elizabeth. 1994. Playing for the Ashes. London, Hodder and Stoughton.

Grisham, John. 1992. A Time to Kill. London, Wynwood Press.

Grisham, John. 2004. The Last Juror. London, Century.

Irving, John. 2001. The Fourth Hand. London, Black Swan. 
Larsson, Stieg. 2005. The Girl with the Dragon Tattoo. Trans. from the Swedish by Reg Keeland (2008). London, MacLehose House.

Lee, Harper. 1960. To Kill a Mocking Bird. Heineman Educational Publishers, Oxford.

Marklund, Lisa. 1998. The Bomber. London, Pocket Books.

Michael Dobbs. 1989. House of Cards. Glasgow, William Collins \& Sons.

Mina, Denise. 2005. The Field of Blood. London, Bantam Press.

Mina, Denise. 2006. The Dead Hour. London, Bantam Press.

Mina, Denise. 2007. The Last Breath. London, Bantam Press.

Neiderman, Andrew. 1990. The Devil's Advocate. London, Random Century Group.

Proulx, Annie. 1993. The Shipping News. London, Fourth Estate.

Waugh, Evelyn. 1938. The Scoop. London, Penguin Books.

Films

Citizen Kane (1941)

Good Night, and Good Luck (2006)

The Insider (1999)

The Paper (1994)

The Pelican Brief (1992)

\section{Secondary references}

Bell, Allan. 1993 [1991]. The Language of News Media. Cambridge, Massachusetts: Blackwell Publishers.

Dooley, Dennis. 1987. "Superman at Fifty - The Persistence of a Legend!" in The Man of Tomorrow and the Boys of Yesterday ed. Dooley, Dennis \& Gary Engle. Ohio, Octavia Press of Cleveland.

Ehrlich, Matthew C. 2002. "Facts, truth, and bad journalists in the movies". Journalism vol. 7(4): 501-519.

Ghiglione, Loren \& Joe Saltzman. 2002. "Fact or Fiction: Hollywood looks at the News", Image of the Journalist in Popular Culture Website, [En ligne] (26/10/2005).

Howard Good. 1986. Acquainted with the Night: The Image of Journalists in American Fiction, 1890-1930. New Jersey, Scarecrow Press.

Isani, Shaeda. 2004. «The genres within the genres ». In Aspects de la fiction à substrat professionnel eds. Michel Petit \& Shaeda Isani, Collection Travaux 2025, 25-36.

Isani, Shaeda. 2005. "From idealisation to demonisation and in-between: representations of American lawyers in legal FASP”. ASp 47/48: 67-81.

Lodge, David. 1992. The Art of Fiction. London, Penguin Books.

Petit, Michel. 1999. "La fiction à substrat professionnel: une autre voie d'accès à l'anglais de spécialité". ASp 23/26: 57-81.

Petit, Michel. 2000. « Le paratexte dans la fiction à substrat professionnel ». Bulletin de la Société de Stylistique Anglaise, 21 Texte et Paratexte. Actes du Colloque de Nanterre. 1999: 173-195.

Pollingreport. 2007. Journalism [En ligne] (15.09.08). 
Saltzman, Joe. 2002. Frank Capra and the Image of the Journalist in American Film. The Norman Lear Center, University of Southern California.

Saltzman, Joe. 2002. "Analyzing the Images of the Journalist in Popular Culture: a Unique Method of Studying the Public's Perception of Its Journalists and the News Media". Image of the Journalist in Popular Culture Website. [En ligne] (12.12.05).

Steinle, Paul. 2000. Print (and Video) to Screen: Journalism in motion pictures of the 1990s [En ligne] (26.10.2005).

The Economist. 2007. "Falling off their Pedestals". $25^{\text {th }}$ May: 41

The Independent. $16^{\text {th }}$ September 2003. Bring Back Clark Kent. [En ligne] (15.09.08)

\section{NOTES}

1. Also referred to as 'new journalism', 'intimate journalism' and 'literary non-fiction'.

2. Meaning 'foundation', 'base'.

3. In keeping with a certain literary tradition in English, the term is not translated and remains FASP as, for example, is the case with roman noir, roman policier, roman à clé, genre, etc.

4. Meaning 'annexe' or 'parallel'.

5. Other elements of comparison: BBC news $-19 \%$, ITV news $-28 \%$, Up-market newspapers $-22 \%$, Mid-market newspapers, $-16 \%$, Red-top newspapers $-7 \%$.

\section{RÉSUMÉS}

Cet article se donne comme objectif d'analyser le journalisme et les journalistes tels que représentés dans la fiction populaire anglo-américaine. Après une brève introduction au genre de la fiction à substrat professionnel (FASP), il ébauche une caractérisation de la FASP journalisme eu égard aux différents degrés de sa conformité avec la FASP. Il propose ensuite une analyse des représentations fictionnelles $d u$ journaliste notamment par rapport à la représentation dichotomique du journaliste en tant qu'individu et en tant que groupe.

This article analyses journalism and journalists as represented in popular Anglo-American fiction. It begins with a brief introduction to fiction à substrat professionnel (FASP) as a genre and analyses the specific traits of the journalism sub-genre with regard to degrees of 'FASPness'. It next analyses fictional representations of journalists with particular reference to dichotomous portrayals of the individual journalist as opposed to the profession as a whole.

\section{INDEX}

Keywords : FASP, journalism FASP, fictional journalists

Mots-clés : FASP, FASP journalistique, journalistes fictionnels 
AUTEUR

SHAEDA ISANI

Université Stendhal-Grenoble 3

ILCEA / GREMUTS 